\title{
The Effect of STEM Project-Based Learning on Students' Scientific Attitude based on Social Constructivism Theory
}

\author{
Harsi Admawati \\ Department of Science Education \\ Graduate School of Yogyakarta State University \\ Yogyakarta, Indonesia \\ Admawati2903@gmail.com
}

\author{
Jumadi \\ Department of Science Education \\ Graduate School of Yogyakarta State University \\ Yogyakarta, Indonesia \\ jumadi@uny.ac.id
}

\begin{abstract}
The purpose of this study was to investigate the effect of STEM project-based learning (PjBL) on students' scientific attitude based on social constructivism theory in natural science learning. One group pre-test and post-test of quasi-experiment was used as research method with junior high school students as the subjects of the research. Data were obtained through a questionnaire. The result of this research indicates that STEM PjBL gives significant effect on students' scientific attitude. It shows that the STEM PjBL can develop students' curiosity, open-mindedness, and cooperation with others. Based on social constructivism theory, this result can be achieved because the learners are able to work effectively with support.
\end{abstract}

Keywords-STEM PjBL, Scientific Attitude, Social Constructivism

\section{INTRODUCTION}

The implementation of STEM education in the classroom provides opportunities for students to understand the importance of the integration of different disciplines, understand STEM applications, increase students' interest in science lessons [1] and demonstrate greater achievement in STEM subjects [2]. However, lacking information on the benefits of integrative approaches to teachers, school administrators do not consider integrative approaches to motivate students' learning in STEM subjects [2], and lacking good STEM curriculum [13] were barriers to implementation. The undergraduate teachers had difficulty to include technology in their lesson and their assessment [11]. Beside that, technology is the hardest discipline to integrate based on teachers perspective[13]. Hence, STEM education research that integrated science, technology, engineering, and math in the students' learning process is needed to investigate the implementation of STEM education and to reduce the barriers.

STEM education is worth implementing regardless of grade levels because students could benefit from the active student-centered learning context provided by integrative approaches [2]. STEM educators can use project-based learning with a set of specific learning outcomes [6]. STEM project-based learning requires collaboration, peer communication, problem-solving, self-directed learning while incorporating rigor for all students [4] and benefits low performing students to a greater extent and decreases the achievement gap [5]. Thus, STEM PjBL has a potential to give effect on students' specific learning outcomes.

Scientific attitude is one of the natural science learning outcomes. Scientific attitude is the ability to react consistently, rationally and objectively in certain ways to a novel or problematic situation that make a person consciously or unconsciously thinks, acts and demonstrates traits that are common to scientists [7]. According to Harlen, curiosity, respect for evidence, critical reflection, perseverance, creativity and inventiveness, open-mindedness, cooperation with others, willingness to tolerate uncertainity, and sensitivity to the environment are the aspects of scientific attitude [3] Methods like experiment, investigation, and project need scientific skills and it will support students' scientific attitude [12]. However, the learning process in Indonesia focuses more on the students' cognitive aspect and less on students' affective aspect [9]. Scientific attitude as one of affective aspect should be investigated in the natural science learning process. This study is aimed to investigate the effect of STEM PjBL on students' scientific attitude. Hence, the contribution of STEM PjBL on students' scientific attitude is clearer. The questions of this study are:

1. Is there any significant effect of STEM PjBL on students' curiosity (scientific attitude aspect)?

2. Is there any significant effect of STEM PjBL on students' open-mindedness and cooperation with others (scientific attitude aspect)?

3. Is there any significant effect of STEM PjBL on students' scientific attitude?

The effect of STEM PjBL on students' scientific attitude will be discussed based on social constructivism learning 
theory. Social constructivism learning theory is a sub-theory which emphasizing on the role of others and all forms of social interaction in the process of constructing knowledge and understanding [14]. Based on social constructivism theory, dialogue becomes the vehicle by which ideas are considered, shared and developed [10].

Vygotsky's notion of the Zone of proximal development (ZPD) is a crucial precept which is central to all of the social constructivist learning theory that describes the difference between what a person can learn on his or her own and what that person can learn when learning is supported by a more knowledgeable other [14]. In the zone of proximal development, a learner is able to work effectively with support and the process of learning involves moving into and across the zone and looking forward to the next level of understanding [10]. To move to the next level of understanding, teachers can give support by scaffolding. Scaffolding is a means by which a "helper" has the potential to provide something which is likely to assist in the process of acquiring knowledge and developing understanding [14]. Scaffolding can be presented through discussion, the provision of materials, or by designing tasks and appropriately support the individual, or a writing frame [10]. As scaffolder, teachers can be as supporter, prompter, critical listener and provider of feedback, simplifier, motivator, highlighter, or model [14]. Additionally, social constructivist teachers focus on helping students find their passions, providing opportunity for social interaction, helping student discover what they care about, helping student create their own learning agendas, providing self-expression through a variety of media, and helping student understand that they are co-constructors of knowledge that they can make sense of things themselves [8].

\section{ReseARCH Method}

This research was quantitative research with one group pre-test and post-test of quasi-experiment. STEM PjBL was applied in the learning process. The pressure concept in the maritime technology was used as a theme in the three activities of students' project.

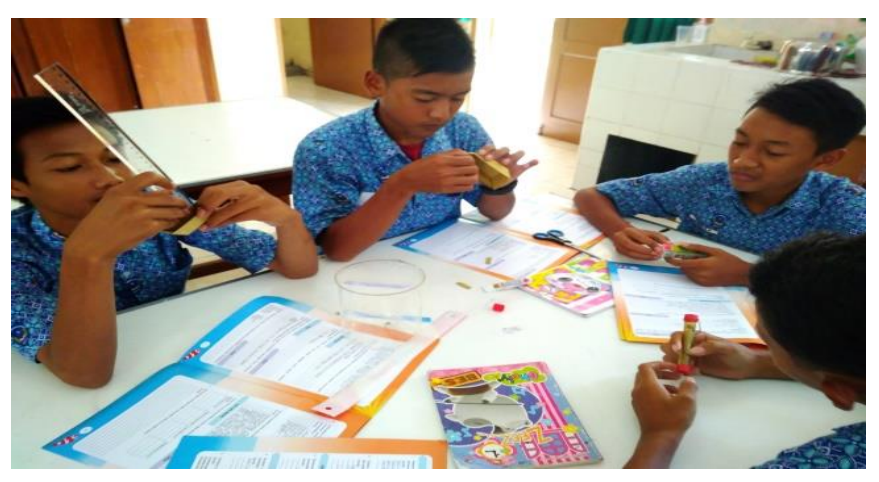

Fig. 1. STEM PjBL Activity
The scientific attitude in this study was concerned with curiosity, open-mindedness, and cooperation with others. Forty-one junior high school students in the 8th grade from two public schools in Yogyakarta were employed in this study. Questionnaire of scientific attitude was used in the pretest and post-test to collect data on students' scientific attitude. To investigate the effect of a STEM PjBL on students' scientific attitude, normality test, homogeneity test, and paired samples T-test statistic were used to analyze data in an SPSS16 program.

\section{RESULT}

The students' scientific attitude could be seen from the pretest dan post-test questionnaire responses. The researchers distributed the questionnaire to 41 respondents before and after STEM PjBL process, the normality of variables was shown in Table I, the homogeneity of variables was shown in Table II, and the effect of STEM PjBL was shown in Table III.

\section{A. Normality}

The p-values from one sample Kolmogorov-Smirnov test were shown in Table I to describe the normality of variables.

TABLE I. NORMALITY

\begin{tabular}{|c|l|c|}
\hline No & \multicolumn{1}{|c|}{ Aspect } & p-value \\
\hline 1 & Curiosity (pre-test) & 0.320 \\
\hline 2 & $\begin{array}{l}\text { Open-mindedness and cooperation with } \\
\text { others (pre-test) }\end{array}$ & 0.408 \\
\hline 3 & Scientific attitude (pre-test) & 0.141 \\
\hline 4 & Curiosity (post-test) & 0.344 \\
\hline 5 & $\begin{array}{l}\text { Open-mindedness and cooperation with } \\
\text { others (post-test) }\end{array}$ & 0.321 \\
\hline 6 & Scientific attitude (post-test) & 0.545 \\
\hline
\end{tabular}

\section{B. Homogeneity}

The Levene's statistics test was used to test the homogeneity of variables. The results of the test were shown in Table II.

TABLE II. HOMOGENEITY

\begin{tabular}{|c|l|c|}
\hline No & \multicolumn{1}{|c|}{ Aspect } & p-value \\
\hline 1 & Curiosity & 0.763 \\
\hline 2 & $\begin{array}{l}\text { Open-mindedness and cooperation with } \\
\text { others }\end{array}$ & 0.856 \\
\hline 3 & Scientific attitude & 0.952 \\
\hline
\end{tabular}




\section{Paired Sample T-test}

Paired sample T-test was used in this research to compare means of pre-test and post-test in one group of students that participated in STEM PjBL process. The results were shown in Table III. Paired sample T-test was used in this research to compare means of pre-test and post-test in one group of students that participated in STEM PjBL process. The results were shown in Table III.

TABLE III. THE RESULTS OF THE PAIRED SAMPLE T-TEST

\begin{tabular}{|c|l|c|c|c|}
\hline No & \multicolumn{1}{|c|}{ Aspect } & Correlation & Sig & p-value \\
\hline 1 & Curiosity & 0.659 & 0.000 & 0.000 \\
\hline 2 & $\begin{array}{l}\text { Open-mindedness } \\
\text { and cooperation with } \\
\text { others }\end{array}$ & 0.618 & 0.000 & 0.011 \\
\hline 3 & Scientific attitude & 0.790 & 0.000 & 0.000 \\
\hline
\end{tabular}

\section{Discussion}

Based on normality table (Table I), p-values of pre-test and post-test on curiosity were higher than $1 / 2 \alpha(\alpha=0.05)$. It indicated that pre-test and post-test on curiosity had the normal distribution. Pre-test and post-test of open-mindedness and cooperation with others had normal distribution because the $p$-values were higher than $1 / 2 \alpha(\alpha=0,05)$. The $p$-values of pre-test and post-test of scientific attitude showed that the values were higher than $1 / 2 \alpha(\alpha=0,05)$. The values indicated that pre-test and post-test of scientific attitude had the normal distribution. Generally, both scientific attitude aspects (curiosity, open-mindedness, and cooperation with others) and scientific attitude had a normal distribution.

The result of homogeneity test in Table II showed that the homogeneity values of pre-test and post-test of curiosity, pretest and post-test of open-mindedness, and cooperation with others, and pre-test and post-test of scientific attitude were higher than $1 / 2 \alpha(\alpha=0.05)$. It denoted that pre-test and post-test of curiosity were homogenous. Pre-test and post-test of openmindedness, and cooperation with others had the same variance from two populations. Pre-test and post-test of scientific attitude were homogenous. Thus, all variables in this study were homogenous.

The result of paired samples correlation on pre-test and post-test of curiosity in Table III indicated that the significant number of correlation in this study was less than $\alpha(0.05)$. Thus, there was a correlation between pre-test and post-test in the learning process of STEM PjBL with correlation value 0.659 . The significant number of 2-tailed samples test in curiosity aspect was less than $0.5 \alpha(\alpha=0.05)$. This results implied that STEM PjBL gave a significant effect on students' curiosity.

Based on Table III, the significant number of correlation in pre-test and post-test of open-mindedness and cooperation with others aspect was 0.000 or less than $\alpha(0.05)$. It showed that there was the correlation between pre-test and post-test in open-mindedness, and cooperation with others aspect with correlation value 0.618 . The result of the significant number of 2-tailed samples test in open-mindedness and cooperation with others aspect was 0.011 or less than $0.5 \alpha(\alpha=0.05)$. It can be concluded that STEM PjBL gave significant effect on openmindedness and cooperation with others aspect.

The significant number of correlation in scientific attitude based on Table III was 0.000 or less than $\alpha(0.05)$. Thus, there was a correlation between pre-test and post-test of scientific attitude in the learning process of STEM PjBL with correlation value 0.790 . The significant number of 2-tailed samples test in scientific attitude was 0.000 or less than $0.5 \alpha$ $(\alpha=0.05)$. This results implied that the effect of STEM PjBL on students' scientific attitude was significant.

The results of this study can be described based on social constructivism theory from Vygotsky. STEM PjBL can develop open-mindedness, and cooperation with others because every student did their project with their peers in the group. Based on Vygotsky, this condition can help a learner work effectively with support, dialogue with peers to share ideas, and move across the zone of proximal development. Besides that, STEM PjBL gave significant effect on students curiosity which indicates social constructivist teachers success on helping students find their passions, helping student discover what they care about, providing self-expression through a variety of media, and helping student understand that they are co-constructors of knowledge that they can make sense of things themselves. Additionally, in this research teachers did scaffolding through discussion, the provision of materials, tasks, and help. Generally, STEM PjBL gave significant effect on scientific attitude because the learner is able to work effectively with support in the zone of proximal development.

\section{CONCLUSION}

Based on the results and discussion in this study, it can be concluded that STEM PjBL can develop students' scientific attitude of curiosity, open-mindedness, and cooperation with others on eighth-grade students. Based on social constructivism theory, this result can be achieved because the learners able to work effectively with support in the zone of proximal development. It showed that STEM PjBL can be implemented in teaching and learning process to improve students' achievement on scientific attitude. This study provides information to reduce the barrier of lacking information on the benefits of integrative approaches to STEM education. The findings should motivate teachers, school administrators, and policymakers to implement STEM PjBL in the teaching and learning process. 


\section{ACKNOWLEDGMENT}

Thank you to the committee of MISEIC UNESA 2018 for providing the opportunity to publish this article.

\section{REFERENCES}

[1] I. Anwari, S. Yamada, M. Unno, T. Saito, I. R. Suwarma, L. Mutakinati, and Y. Kumano, "Implementation of authentic learning and assessment through STEM education approach to improve students' metacognitive skills", K-12 STEM Education, vol. 1, no. 3, pp. 123-136, 2015.

[2] K. Becker and K. Park, "Effects of integrative approaches among Science, Technology, Engineering, and Mathematics (STEM) subjects on students' learning: a preliminary meta-analysis", Journal of STEM Education: Innovations and Research, vol. 12, no. 5/6, p. 23, 2011.

[3] P. Bundu, Penilaian keterampilan proses dan sikap ilmiah dalam pembelajaran Sains SD, Jakarta: Depdiknas, 2006.

[4] R. M. Capraro and S. W. Slough, "Why PBL? Why STEM? Why now? An introduction to STEM Project-Based Learning", In STEM ProjectBased Learning, 2013, pp. 1-5

[5] S. Han, R. Capraro, and M. M. Capraro, "How Science, Technology, Engineering, and Mathematics (STEM) Project-Based Learning (PBL) affects high, middle, and low achievers differently: the impact of student factors on achievement", International Journal of Science and Mathematics Education, vol. 13, no. 5, pp. 1089-1113, 2015.

[6] T. J. Kennedy and M. R. L. Odell, "Engaging students in STEM education". Science Education International, vol. 25, no. 3, pp. 246-258, 2014
[7] K. J. Olasehinde and R. A. Olatoye, "Scientific attitude, attitude to science and science achievement of senior secondary school students in Katsina State", Nigeria Journal of Educational and Social Research, vol. 4, no. 1, p. 445, 2014.

[8] P. Oldfather, J. West, J. White, and J. Wilmarth, Learning through children's eyes, Washington, DC: American Psychological Association, 1999.

[9] M. Misbah, D. Dewantara, S. M. Hasan, and S. Annur, "The development of student worksheet by using Guided Inquiry Learning Model to train student's scientific attitude", Unnes Science Education Journal, vol. 7, no. 1, 2018.

[10] A. Pritchard, Ways of learning: learning theories and learning styles in the classroom, Routledge, 2013.

[11] T. Saito, Y. Gunji, and Y. Kumano, "The problem about technology in STEM education: some findings from action research on the professional development \& integrated STEM lessons in informal fields", K-12 STEM Education, vol. 1, no. 2, pp. 85-100, 2015.

[12] E. Suryawati, K. Osman, and T. S. M. Meerah, "The effectiveness of RANGKA contextual teaching and learning on students' problemsolving skills and scientific attitude", Procedia-Social and Behavioral Sciences, vol. 9, pp. 1717-1721, 2011.

[13] H. H. Wang, T. J. Moore, G. H. Roehrig, and M. S. Park, "STEM integration: teacher perceptions and practice", Journal of Pre-College Engineering Education Research (J-PEER), vol. 1, no. 2, p. 2, 2011.

[14] J. Woollard and A. Pritchard, Psychology for the classroom: constructivism and social learning, Routledge, 2013. 